\title{
Concluding reflections
}

\author{
Laurie Johnston
}

God could be considered the first miner. In Genesis, God draws dirt out of the earth, shapes it, and transforms it into human persons. Created in the image of God, we are invited to share in that creative work, and so we too turn the earth for the raw materials it requires. It is impossible to conceive of the human vocation on earth without mining, for "everything that comes from man throughout the whole process of economic production ... presupposes these riches and resources of the visible world, riches and resources that man finds and does not create" (John Paul II 1981, \$12). The precious minerals that we find in the earth are part of God's generosity and the goodness of creation, as Cardinal Turkson points out in the first chapter of this volume. Yet, like all of creation, they are in "bondage to decay" as a result of $\sin$ (Rom. 8:20-21). As the chapters throughout this volume reveal, mining projects have often revealed the extent of human sin, violence, and injustice. Mining presents a serious challenge to Christians' witness to God's redemption of all creation and our vocation to become artisans of an ecological just peace.

\section{Examining the roots of a complex problem}

The connection between violent conflict and mining has complex causes, contours, and possible solutions. As the case studies from Section 1 reveal, there are many sites of extraction where the "cry of the poor" and the "cry of the earth" ring out in unison. Querida Amazonia summarizes:

The businesses, national or international, which harm the Amazon and fail to respect the right of the original peoples to the land and its boundaries, and to self-determination and prior consent, should be called for what they are: injustice and crime. When certain businesses out for quick profit appropriate lands and end up privatizing even potable water, or when local authorities give free access to the timber companies, mining or oil projects, and other businesses that raze the forests and pollute the environment, economic relationships are unduly altered and become an instrument of death. They frequently resort to 
utterly unethical means such as penalizing protests and even taking the lives of indigenous peoples who oppose projects, intentionally setting forest fires, and suborning politicians and the indigenous people themselves. All this accompanied by grave violations of human rights and new forms of slavery affecting women in particular... (Francis $2020, \$ 14)$

While this refers specifically to the Amazon, mining and conflict are often "locked in an escalating spiral," as Karl Gaspar puts it. Similar attitudes, theologies, and value systems seem to underly both violence against the earth and violence against people, shaping the social sin of "extractivism":

Extractivism is a short-sighted model of development seen around the world that exploits natural resources on a massive scale, creating significant economic profits for the powerful few in the short term, but too often resulting in minimal benefits for the communities where these resources are found. (Inter-Religious Working Group on Extractivism 2019)

When the profit motive is supreme, it is easy to overlook the fact that resources are limited and will eventually be exhausted. Holden and Montevecchio write, "What the extractivist paradigm never contemplates is a cessation of extraction; the ideas of removing less from the earth ... or else changing consumption patterns altogether are never considered."

Extractivism is a corollary to what Pope Francis has called "throwaway culture." The term powerfully expresses the interconnected evils evident in the world today, reflected in human attitudes and behavior but also in economic and political structures. Like throwaway culture, extractivism is rooted in a disavowal of connectedness. It seeks only how to use resources, and often other people, whether through slavery, colonial domination, or other forms of dehumanization. For centuries, extraction has been a central motivation for colonial and imperial expansion and has been associated with many forms of violence, particularly against the bodies of women and indigenous peoples. Thus, the problems that are described in this volume are neither new nor particularly surprising.

Mining plays an enormous role in human flourishing today, too. As William George $(2019$, x) has said, "Everything begins with mining." Virtually anything we touch comes from extraction. Moreover, the transition to renewable energy requires minerals to manufacture solar panels, batteries, and other green technologies; the fate of the planet depends upon the continuation of mining. Yet its fate (and the fates of many humans) are also threatened by what is fundamentally an unsustainable enterpriseminerals do not renew themselves. This is why some of the authors in this volume question whether mining can ever be done ethically. Raymond Offenheiser describes some of the significant improvement major mining 
companies have made, but there is no doubt that extraction always comes with moral perils and environmental risks. In some places, those risks are simply too great; Andrés McKinley explains how Salvadorans came to conclude that their country was one of those places. Still, mining will continue, which is why we must, as Tobias Winright says, try to limit the evils associated with it. This requires a holistic response-a truly integral approach to peacebuilding.

\section{Challenges and opportunities}

When it comes to engaging this nexus of mining, violence, and ecological destruction, what do Catholic peacebuilders have to bring to the table? There are a number of important resources and opportunities that emerge from the Catholic tradition, and some significant challenges.

\section{Peace as the fruit of right relationships}

Catholic social teaching frequently reminds us that peace is the fruit of right relationships. This volume has illustrated breakdowns in many types of relationship, and peacebuilding in the context of mining requires attention to each of them. Authors in this volume have addressed the complex triad of mining companies, national governments, and local communities where mining takes place. On the one hand, it is clear that communities need practical and pastoral assistance in holding their governments accountable. When governments receive significant portions of their income from mining, they are more likely to look away while local communities are displaced, face ecological damage, or experience human rights violations at the hands of private security forces (or even national police). On the other hand, even when governments do seek to protect the interests of their citizens, they are at a significant disadvantage; large mining companies have technical, informational, financial, and legal resources that outmatch most governments in the Global South. Many countries have faced lawsuits from deep-pocketed mining companies seeking to preserve their exploitation rights. Finally, even mining companies seeking to do the right thing may encounter obstacles from government officials or local militias who seek to extort them, or competition from other mining companies who are less scrupulous. In this context, peacebuilders who seek to promote just relationships must find ways to empower local communities to hold governments accountable, promote good governance for the common good, and continue to push both large and smaller mining companies to conduct themselves in more and more ethical and sustainable ways.

Another important triad is the relationship between governments, citizens, and mining companies in the countries where these mining companies are based. As Vincent Miller points out, citizens of wealthy countries are largely in the dark about the sourcing of consumer products; they enjoy 
many of the benefits of extractive industries while bearing few of the costs. Governments of wealthy countries are often captive to mining interests, too; William Holden's account of the Canadian ambassador in Guatemala intervening on behalf of Canadian mining interests is a telling one. A key task, then, is finding ways to make citizens of wealthy countries more aware of the human and ecological consequences of their consumer behavior-not only to incentivize changes in this behavior, but so that they will push their governments to establish laws and policies that will bring about shifts in the global economic system, such as Dodd-Frank and some European countries' emerging laws about responsible multi-national corporations. These wealthy countries also play an outsize role at the WTO, at the UN, and in governing the World Bank, all of which play important, but distinct, roles in shaping the global economic system and the mining industry.

The Catholic Church has a powerful ability to bear witness to what is happening in many different places around the world. Several times in the past decade, major mining executives have attended meetings at the Vatican-in part because they realize that the church is present in nearly all the countries in which they operate. This broad reach is important precisely because mining takes place in remote areas where oversight is difficult and government authorities may be quite limited. Human rights violations can take place with relative impunity. The coronavirus pandemic has made oversight and monitoring even more difficult. And while major mining companies have made progress towards more ethical practices, small and mid-range mining operations frequently remain opaque. Thus, the Catholic Church's ability to monitor mining projects and advocate for local communities will continue to be important. Earlier chapters in this volume testify to the variety of ways the church has played this role, from assessing contracts in the Democratic Republic of the Congo (DRC), to conducting pastoral surveys in Colombia, to issuing pastoral letters like the Philippine bishops' "What is Happening to Our Beautiful Land?"

Oversight and monitoring are greatly aided by transparency. As the Extractive Industries Transparency Initiative makes more information about mining operations and contracts accessible, it is important for there to be an informed public that can consume this information and compare it with realities on the ground. The church's ability to bear witness is thus an important adjunct to the ongoing push for greater transparency. However, this also poses a challenge to Catholic leaders: much like mining companies, the Catholic Church does not have a strong tradition of institutional transparency. Furthermore, the church can itself be vulnerable to the potentially corrupting influence of donations from those with vested interests in extractive industries. Catholic University of America has been criticized for accepting millions of dollars from the Koch Foundation, given that the Koch brothers are oil magnates who have sought to protect extractive industries by funding climate skeptics and lobbying against policies that aim to reduce global warming (McElwee 2013). 
In the Philippines, Father Benvenido Miguel has criticized Catholic leaders for soliciting donations from mining companies, and even accepting cars and hotel vouchers: "Asking favors or accepting gifts from companies 'creates a perception that they can buy and silence the Church' on issues of environmental protection" (Saludes 2020, n.p.). Such potentially corrupting forces exist in many Catholic contexts; the best protection against them is ensuring a strong commitment to internal and external transparency as a key component of the church's witness. Right relationships among all in society, not merely cozy relationships between elites, are the key to sustainable peace.

\section{Becoming truly "catholic"}

In addition to bearing witness to what is happening in local communities around the world, a second important role for the church is creating connections among Catholics and between Catholics and other groups. According to McKinley, Catholic leaders facilitated a visit from a Philippine governor that was instrumental in convincing communities and politicians in El Salvador to be skeptical of the role mining might play in their country. The testimony of a Congolese bishop before the US Congress, supported by the US Catholic bishops, helped garner support for Dodd-Frank. Ecclesial networks can help connect those who bear the impact of mining in different countries in order to, as Offenheiser puts it, "link grievances at the community level to patterns of abuse at the national and global level and then turn the observation of these patterns into very specific policy recommendations to the industry." Miller calls especially for linking those impacted by mining with consumers and political leaders in wealthy countries that benefit from mining, to create "deeper relationships of solidarity." This book is itself an attempt to contribute to that effort.

Mining also offers many opportunities for collaboration with groups outside the church. In fact, the Catholic Church is somewhat late to the party; Oxfam and other organizations have played major roles in pushing for ethics and sustainability in the extractive industries, and the church can benefit from their expertise. Partnerships with other religious communities are also vital, particularly in places like the Philippines and Mozambique where there are overlaps between religious conflicts and mining-related conflicts. Elias Opongo has argued that these sorts of broad coalitions are key for church action to be effective, especially at the level of governance and policy. As Katherine Marshall points out, there is often no "accepted 'place' for religious engagement in many of the international debates that affect extractive industry policies or in efforts to address problems that arise." Yet by forming alliances, religious actors can have a better chance of gaining a place at the table.

Building these intra-ecclesial and extra-ecclesial connections raises ecclesiological questions, however. First, several of the authors in this volume 


\section{Laurie Johnston}

call for a greater role for the laity, given that technical expertise is vital in engaging with mining. At the same time, it is clear that clergy, especially bishops, have a high level of visibility and moral authority in countries like the DRC, and therefore have a very important role to play. In other contexts, Catholic laypeople, religious orders, universities, and civil society organizations have taken the lead. Of course, there may also be significant overlap between the efforts of laity, religious, and clergy; DHUMA, as described by José Bayardo Chata Pacoricona, offers an interesting example of an organization that began from a collaboration between bishops, religious congregations, and lay parish workers, and now operates as an independent civil society organization while maintaining its Catholic identity.

Perhaps the greatest challenge for Catholic engagement in mining is finding ways to truly incorporate women's voices and leadership. The leadership of the mining industry and the leadership of the institutional church are both male-dominated. Yet the greatest negative impacts of mining accrue to women. Mining is nearly always accompanied by sexual exploitation of various kinds, and the conflicts that surround mining involve gender-based violence on a massive scale. The environmental effects of mining also burden women in particular: in many contexts, it is they who are primarily responsible for farming and for supplying water to their families. Yet their concerns are frequently overlooked; even when community consent processes do take place, they often neglect women's participation and fail to account for social structures and mores that inhibit that participation.

At the same time, women are frequent activists for justice in and beyond mining communities; their approaches have much to teach others who are seeking to promote an ecological just peace. For instance, indigenous women in Guatemala have called attention to the importance of thinking about the long-term. One activist explained, "Women take the time to think: what will happen tomorrow? Or what will I do tomorrow? Men do not think this way" (Deonandan, Tatham, and Field 2017, 409). Other women have found creative ways to push back against the exploitation of their bodies that frequently accompanies extractive industries. In South Africa, women seeking employment in the mines were angered by incidents of men demanding sex in exchange for a job. To push back, women in Mpumalanga adopted the slogan, "My body is not my CV" (WoMin African Alliance 2020). There are many other cases; a major weakness of this present volume is that it does not give sufficient attention to these voices and examples. While Catholic engagement-including recent Vatican meetings-has frequently included women religious, real gender justice requires much more. Environmental activists have coined the term "greenwashing" to refer to shallow or disingenuous attempts to appear environmentally responsible. The term "pinkwashing" can refer to analogous attempts to include women's voices while still excluding them from power structures and from determining the overall agenda. Both the church 
and mining companies must pay particular attention, then, to the critiques coming from organizations like WoMin in Africa.

\section{Seeking the common good}

The violent conflicts that often emerge around mining illustrate what happens when certain goods or resources are pursued without attention to a larger common good. Authors in this volume have discussed the common good, the ecological common good, and even the cosmic common good. However, when there are conflicting interests in society, determining how best to promote the common good is difficult. When mining executives arrived at the Vatican for a day of reflection in 2013, Vatican Secretary of State Tarcisio Bertone said: “The great challenge of business leaders is to create a harmony of interests, involving investors, managers, workers, their families, the future of their children, the preservation of the environment on both a regional and international scale, and a contribution to world peace" (Vatican Radio 2013, n.p.). However, it is a real question whether such a "harmony of interests" is actually possible. Kenneth Himes has noted that a "failure to acknowledge the deeply conflictual nature of human reality has permitted Catholic social teaching to remain underdeveloped in strategies of conflict resolution" (Himes 2010, 282-3). Human sinfulness and the conflictual nature of reality mean that tensions around mineral resources are to be expected. There are situations where there is no "win-win" outcome, and Catholic social teaching has not always accounted for these well. If a community rejects a mining project, investors lose money and resources for potentially good ends are lost; it is not surprising that mining companies remain reluctant to fully embrace the idea that they must respect community consent as a binding principle, as it might mean abandoning promising projects on which millions of dollars have already been spent.

Still, there are areas of common interest between extractive industries and local communities, and the Catholic Church can play a role in finding these, for the sake of the common good. Many of the largest mining companies have come to understand that upfront investment in good relationships with local communities is in their best interests, particularly because this may prevent conflict, fines, and even premature mine closures. Some mining companies have been in favor of greater financial transparency; they want to disarm opposition by proving that they are paying their fair share and ensuring that their payments are not lost to corruption. Another possible area of common interest is infrastructure development. Mining endeavors frequently require companies to develop electric, water, and transportation infrastructure; it is often possible to do this in a way that will offer lasting benefits to local communities. Albino Barrera describes the problem of "export enclaves," and partnering with local communities to develop this infrastructure could be a good way to break away from that enclave model. To capitalize upon this, there is a need for community leaders who can 
liaise with mining companies and government officials in order to find these areas of common interest, and local church leaders and women religious can and do play that role.

\section{Prophecy vs. collaboration}

One challenge that Catholic leaders face is this: when should they take a stance of collaboration, and when should they focus on holding companies accountable or opposing their work outright? Given the devastating effects of mining on people and the environment, a prophetic critique seems like the appropriate response in many circumstances. Daniel Finn (2017, n.p.) agrees, but also calls for a nuanced understanding of the church's prophetic role:

[T] he way to get abusive mining companies to shift to the new paradigm is to make it less arduous for the responsible firms than for the irresponsible ones. The world needs a prophecy that remains open to the possibility of authentic transformation. And where transformation does indeed occur, prophets need to shift their methods toward civil engagement for a more just and sustainable world. Finn 2017

It is difficult to find a mode of public engagement that holds corporations and governments accountable while resisting the temptation to demonize the people within these institutions. Catholics seeking to engage mining companies must strike a difficult balance: how do we recognize moral progress but maintain a healthy skepticism about an industry where the human risks, environmental risks, and moral hazards are enormous?

Questions around incremental moral improvement are a challenge in many areas of ethical reflection. Roger Burggraeve (1994) has sought to address them through an "ethics of growth." This approach is rooted in the idea that even when individuals are in clear violation of moral norms, that does not mean the task of providing moral guidance ends. Rather, the church should examine how to help all persons continue to grow in the moral life. Such an approach can provide a way for Catholic activists who oppose most mining in principle to nevertheless seek ways to make sure it is conducted less harmfully. Similarly, an "ethics of growth" can be a way to describe how Catholic peacebuilders engage violent actors in moving towards peace, while not overlooking the real evils for which these actors may be responsible. Such an approach testifies to faith in the redeeming power of God that may emerge in any situation, bringing the common good to fruition despite obstacles.

\section{The longue durée of war and mining}

A key strength of Catholic peacebuilding has been its focus on a broad time horizon. Scott Appleby $(2010,3)$ has defined peacebuilding as "conflict 
transformation that strives to comprehend the longue durée of a conflict." Political attempts at peacemaking fail because of their short time horizon; a Catholic vision of what peace requires is far more holistic and requires us to take a long view and strive for something more sustainable. Creating a just peace requires attention to root causes that may be long in the past, as well as a commitment to persevere in practices of peacebuilding that may take generations to bear fruit. Recently, theorists of jus post bellum have called for greater attention to the long-term consequences of war. What is wrong about war is not just the destruction that happens during war, but the aftereffects for both people and the earth: landmines, depleted uranium, unexploded ordnance, napalm-poisoned soil. Traumatized communities may take generations to be reconciled.

The ethics of mining also has a challenge with time-and we have seen already that this is an area of particular critique from women activists. While some mining companies have embraced the idea of planning for a mine's ultimate closure from the very beginning, others have been slow to embrace the idea of responsibility for the entire lifecycle of a mine. For instance, when a large mining company has exhausted the high-quality ores in a mine, they may sell it off to a smaller mining company that may choose to mine lower-quality ores (which is likely to be less efficient and more disruptive) and then hurriedly close the mine without doing the appropriate cleanup or without ensuring the stability of tailings dams. Even when a mining project begins responsibly and obtains community consent, mining personnel may change over time, and important policies and practices may slide into oblivion. As Holden and Montevecchio point out in their chapter, the geologic timescale of these undertakings is vast-particularly when it comes to radioactive ores-and so perpetual attention is required.

How, then, can we cultivate forms of social virtue that endure for the long term? Law can help to serve this purpose, of course-and so it is important, as Offenheiser and Douglass Cassel urge, to continue the push for hard law that protects the earth and empowers communities (not just voluntary principles, as many mining companies would prefer). But this is also a task for churches, as spaces of formation, education, and memory. Pope Francis' call for intergenerational solidarity in Laudato Si' is an important way to nurture our attention to a longer time frame. Churches can do more to link liturgical practices to advocacy, perhaps by calling attention to the ways that mining often threatens the water that we use for baptism and the farmland on which wheat is grown for the Eucharist. Also, Sandra Polanía-Reyes and Héctor Fabio Henao describe how the Church in Colombia has focused intently on pastoral work to help communities become more attuned to a theology of creation.

The doctrine of creation is vitally important as a justification for care for the earth. However, Catholics also must understand environmental activism from the broader perspective of eschatological time. As the Scheids point out, the Christian mandate to respect the earth is also rooted in a 
vision of its destiny. In Laudato Si, Pope Francis $(2015, \$ 243)$ calls us to care for our earthly home "which has been entrusted to us, knowing that all the good which exists here will be taken up into the heavenly feast." What we do to nature matters, because the earth will share with us in the final salvation that is coming. In his epistle to the Romans, Paul tells us that "All of creation is groaning in anticipation ..." of redemption, and that includes the rocks and ores in the ground. Of course, the Scheids point out that "bearing in mind our shared eschatological future or the full cosmic import of our choices will not fully or even perhaps partially determine concrete practical political solutions toward peacemaking and social justice." Still, it is possible that we need to abandon a key idea that moral theologians have used for centuries- "the universal destination of created goods." The idea that God destined creation to be used by all of humanity is a powerful way to limit excessive wealth or the hoarding of mineral resources by just a few. Pope Francis uses this phrase in Laudato Si, and it would be excellent if humans could even come close to the sharing to which that phrase calls us. But in the Anthropocene, we must no longer speak about the earth as "destined" for human consumption. Yes, we can and should use the goods of the earth, in a way that is proportional, as Winright suggests. But the earth has its own destiny and dignity, even, perhaps, its own rights. Better, then, to think of friendship with the earth as we move together towards our shared redemption. By merging the idea of integral ecology with Pope Francis' (2020) call for social friendship in Fratelli Tutti, we can cultivate a new practice of ecological friendship.

When there are broken relationships, however, moving towards friendship with the earth requires reconciliation. Reconciliation is a major theme of Catholic peacebuilding; lasting peace is impossible without it, as many conflicts around the world have shown. But how do we reconcile with the earth that we have damaged? Truth-telling and acknowledgment of environmental damage for which we are responsible are certainly important, as are reparations that seek to restore ecosystems. Memorialization is also vital, partly for the sake of future generations who might forget just how much damage can be done to both humans and the earth by unbridled extractivism. In particular, it is important to acknowledge the damage that is done when people are displaced from their land-a particular kind of broken relationship that is common in the context of mining. As Clemens Sedmak writes, "When rural or indigenous communities face losses from a mining project that is supposedly good for economic development, they may officially gain access to higher 'living standards,' but they lose identity-conferring aspects of their lives." Loss of identity is a key driver and consequence of many violent conflicts around the world. Finding ways to acknowledge this kind of deep loss in the liturgical life of the church is key for building peace and bringing healing in human communities and with the earth as well-even if the true peace we long for will arrive only at the eschaton. 


\section{A peacebuilding lens as a new way of seeing}

Pope Francis reminds us that there is no single solution to the interconnected challenges we face today. In fact, technological specialization often makes it "difficult to see the larger picture" (Francis 2015, $\$ 110$ ). Instead, he says, "There needs to be a distinctive way of looking at things, a way of thinking, policies, an educational programme, a lifestyle and a spirituality which together generate resistance to the assault of the technocratic paradigm" (\$111). The chapters in this volume are an invitation to look at mining-related conflicts in a more holistic way. The task also invites us to see our own tradition and Scriptures in new ways. Perhaps Isaiah's vision of peace can also be a reminder about the careful repurposing of the earth's minerals: "they shall beat their swords into ploughshares, and their spears into pruning-hooks" (Is. 2:4). An ecological just peace requires us to see the intrinsic dignity of one another and of the earth itself, in light of our shared destiny. Such a transformed way of looking at the world ultimately requires conversion from all of us.

\section{References}

Appleby, R. Scott. 2010. "Peacebuilding and Catholicism: Affinities, Convergences, Possibilities." In Peacebuilding: Catholic Theology, Ethics, and Praxis, edited by Robert J. Schreiter, R. Scott Appleby, and Gerard F. Powers, 3-22. Maryknoll, NY: Orbis.

Burggraeve, Roger. 1994. "Une éthique de miséricorde." Lumen Vitae 49: 281-296. Deonandan, Kalowatie, Rebecca Tatham, and Brennan Field. 2017. "Indigenous Women's Anti-Mining Activism: A Gendered Analysis of the El Estor Struggle in Guatemala." Gender \& Development 25, no. 3: 405-419. 10.1080/13552074. 2017.1379779.

Finn, Daniel. 2017. "Recycling isn't enough: A Defense of Responsible Mining." Commonweal, May 2, 2017. https://www.commonwealmagazine.org/recyclingisn't-enough.

Francis. 2015. Laudato Si'. http://www.vatican.va/content/francesco/en/encyclicals/ documents/papa-francesco_20150524_enciclica-laudato-si.html.

Francis. 2020. Querida Amazonia. http://www.vatican.va/content/francesco/en/ apost_exhortations/documents/papa-francesco_esortazione-ap_20200202_ querida-amazonia.html.

Francis. (2020). Fratelli Tutti. https://www.vatican.va/content/francesco/en/encyclicals/ documents/papa-francesco_20201003_enciclica-fratelli-tutti.html.

George, William P. 2019. Mining Morality: Prospecting for Ethics in a Wounded World. Lanham, MD: Lexington Books.

Inter-Religious Working Group on Extractivism. 2019. "A Just Response to Extractivism." https://justresponse.faith/node/3.

John Paul II. 1981. Laborem Exercens. https://www.vatican.va/content//ohn-paulii/en/encyclicals/documents/hf_jp-ii_enc_14091981_laborem-exercens.html.

McElwee, Joshua J. 2013. "Republican Donors' Gift to Catholic University Comes Under Fire." National Catholic Reporter, December 16, 2013. https://www.ncronline. org/news/politics/republican-donors-gift-catholic-university-comes-under-fire. 


\section{Laurie Johnston}

Saludes, Mark. 2020. "Some Philippine Catholic Church Institutions Accept 'Dirty Donations." Licas News, September 29, 2020. https://www.licas.news/2020/ 09/29/some-philippine-catholic-church-institutions-accept-dirty-donations/.

Himes, Kenneth. 2010. "Peacebuilding and Catholic Social Teaching." In Peacebuilding: Catholic Theology, Ethics, and Praxis, edited by Robert J. Schreiter, R. Scott Appleby, and Gerard F. Powers, 265-299. Maryknoll, NY: Orbis.

Vatican Radio. 2013. "Pope Hopes Day of Reflection on Mining Ethics Will Benefit Industry, Workers.” http://www.archivioradiovaticana.va/storico/2013/09/09/pope_ hopes_day_of_reflection_on_mining_ethics_will_benefit_industry,/en1-726839.

WoMin African Alliance. 2020. "Women Stand Their Ground Against Big Coal." https://womin.africa/download/women-stand-their-ground-against-big-coal-final/. 